\title{
A Study on Groundwater Recharge and Fluctuation of Vadrapalem Village in Madakasira Mandal of Andhrapradesh, India
}

\author{
B. Laxman ${ }^{1 *}$, M.V. Ramana ${ }^{2}$ and S. Tirupathi ${ }^{3}$ \\ ${ }^{1}$ FIM Scheme, Rajendranagar, Hyderabad, PIN 500030, India \\ ${ }^{2}$ RARS, Tirupathi, A.P, India \\ ${ }^{3}$ College of Agricultural Engineering, Madakasira, ANGRAU, India \\ *Corresponding author
}

\section{A B S T R A C T}

\begin{tabular}{|l|}
\hline Ke y w or d s \\
Pennar, Ground \\
water, Vadrapalem, \\
Fluctuation, River \\
\hline Article Info \\
\hline $\begin{array}{l}\text { Accepted: } \\
\text { 10 June } 2018 \\
\text { Available Online: } \\
\text { 10 July } 2018\end{array}$ \\
\hline
\end{tabular}

\section{Introduction}

Ground water characteristics of the Ananthapuramu

Pennar and some parts of Krishna basins are drained in this district, mainly Pennar River enters the southern part of the district from Karnataka state near chavlum village near Hindupur town and Vedavati River drains predominantly in the western part of district, which is a tributary to Tungabhadra. Pennar and its tributaries like Chitravati, Papagni, Maddileru, Tadakaluru, Maravanka and nearly, 80 percent of the district is drained by the river. Ananthapuram district is divided into 90 minor basins. The chief sources of Irrigation in the district are tanks, wells and canals. The major irrigation project in the district is Tungabhadra high level canal project Stage- I and II with an ayacut of 51,771 ha and 6 medium irrigation projects. Apart from irrigation projects, there are 5353 irrigation tanks and about 87,000 wells. The gross irrigated area is $1,54,000$ ha and the net irrigated area is $1,25,000$ ha in the district. Out of net area irrigated area of 31 percent is from surface water irrigation and 69 percent is from ground water irrigation. 


\section{Depth to water level}

Ground water levels were monitored from a network of 71 observation wells four times in a year. These observation wells, tapping the phreatic aquifer, include dug wells and shallow bore wells. The State Ground Water Department has also established 144 observation wells and 70 piezometers with 61 automatic water level recorders. The depth to water level during pre-monsoon (2005) range from 2.53 to $19.67 \mathrm{~m}$ below ground water level. The shallow water levels of $<5 \mathrm{~m}$ are observed in Northern and South Eastern part of the area. The depths to water levels between 5-10 $\mathrm{m}$ are observed in North Western part and Eastern part of the area. Deeper water levels of $>10 \mathrm{~m} \mathrm{bgl}$ are observed in majority of the district.

\section{Water level fluctuation}

Majority of the district shows rise in water level between pre and post monsoon period of 2005 (2-4 m). Rise of water level up to $2 \mathrm{~m}$ is observed in North Western and Southern parts of the district. Rise of water level of $>4 \mathrm{~m}$ is observed in North Eastern part of the district. Water level fall of $2 \mathrm{~m}$ is observed in North Western fringe of the district. Less fluctuation is observed in the areas where the water levels were comparatively shallow during premonsoon and where the slope is less.

\section{Materials and Methods}

\section{Soil water balance method}

Water balance models were developed in the 1940s by Thornthwaite (1948) and were later revised. The method is essentially a bookkeeping procedure, which estimates the balance between the inflow and outflow of water. Here, the volume of water required to saturate the soil is expressed as an equivalent depth of water and is called soil water deficit.
The soil water balance can be represented by, $\mathrm{R}_{1}=\mathrm{P}-\mathrm{E} \mathrm{a}+\Delta \mathrm{W}-\mathrm{R}_{\mathrm{n}}$

Where, $\mathrm{R}_{1}=$ recharge

$\mathrm{P}=$ precipitation

$\mathrm{Ea}=$ evapotranspiration $(60 \%)$

$\Delta \mathrm{W}=$ change in water stage

$\mathrm{R}_{\mathrm{n}}=$ runoff water (40\% of rainfall)

\section{Results and Discussion}

The results obtained from the present investigation as well as relevant discussion have been summarized under following heads:

Data on below ground water recharge for Vadrapalem village Madakasira Mandal (mm)

The piezeometric water levels are obtained from the Vadrapalem village, Madakasira mandal for the period 2001-2012. It has been observed that all the years. January to June there was absolutely no recharge at all the 11 years. There was minimum recharge (fluctuations) from June to December months and all the years highest ground water recharge in 2008, September the ground water fluctuations was peak i.e. $12320 \mathrm{~mm}$ i.e. 12.32 $\mathrm{m}$ from this analysis we can design the crop calendar based on ground water recharges and also it has been from the January to July are driest months in this region. Whatever the little recharge takes place i.e. July to December months only as shown Figure 1.

Data on below ground water fluctuation for Vadrapalem Village Madakasira Mandal (mm)

Below ground water level data was obtained from the ground water department, government of Andhrapradesh for Vadrapalem village, Madakasira Mandal. The piezeometric levels recorded for 2001-2012 were obtained as analyzed from the data. 
Fig.1 Below ground water level fluctuation during the period 2001-2012 in Amudalagandi

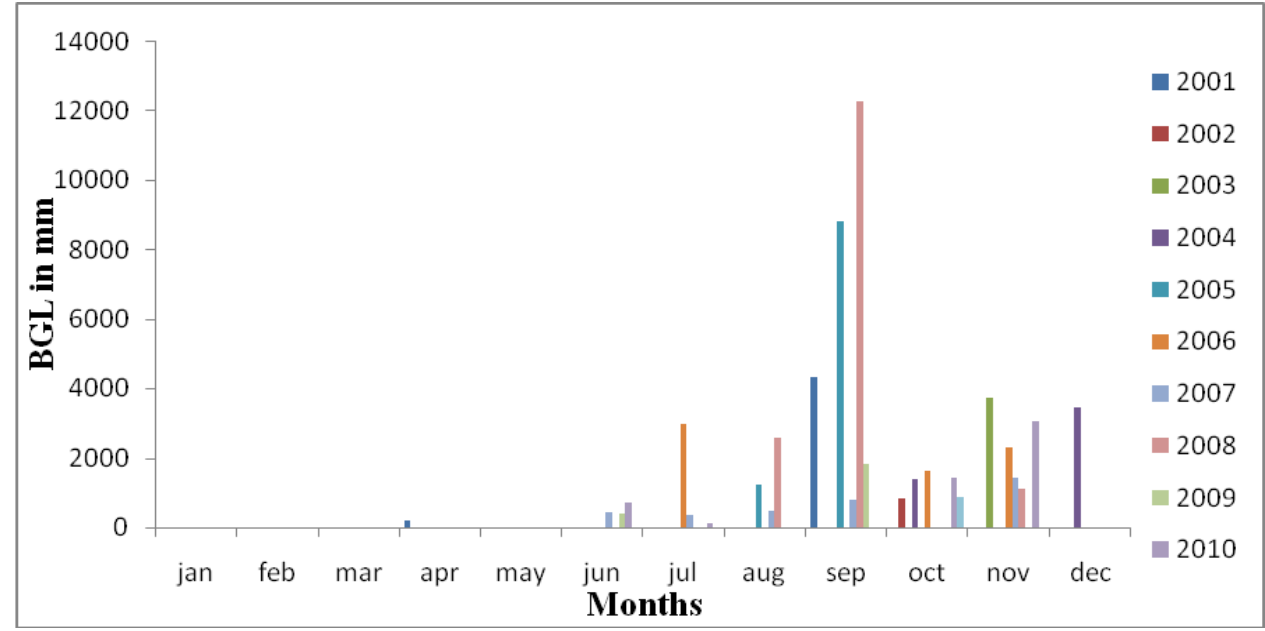

Fig.2 Ground water fluctuation during 2001-2012 in Vadrapalem village

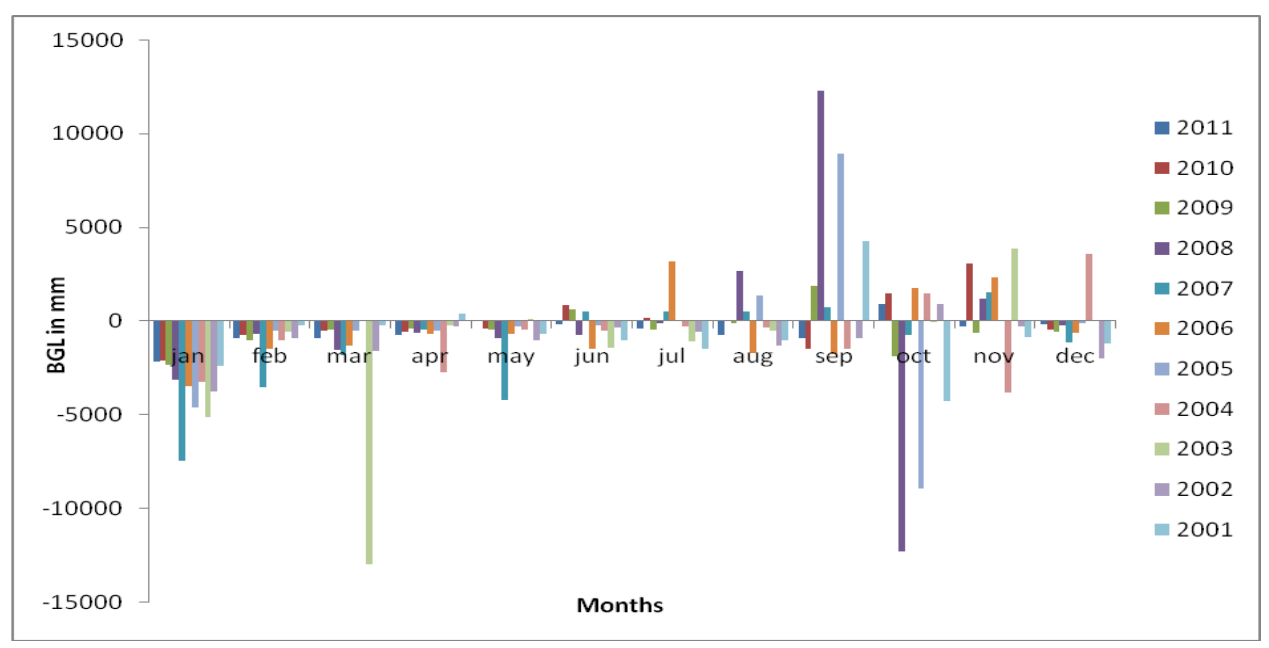

Fig.3 Ground water table fluctuation based on 12 years (2001-2012) data in Vadrapalem village

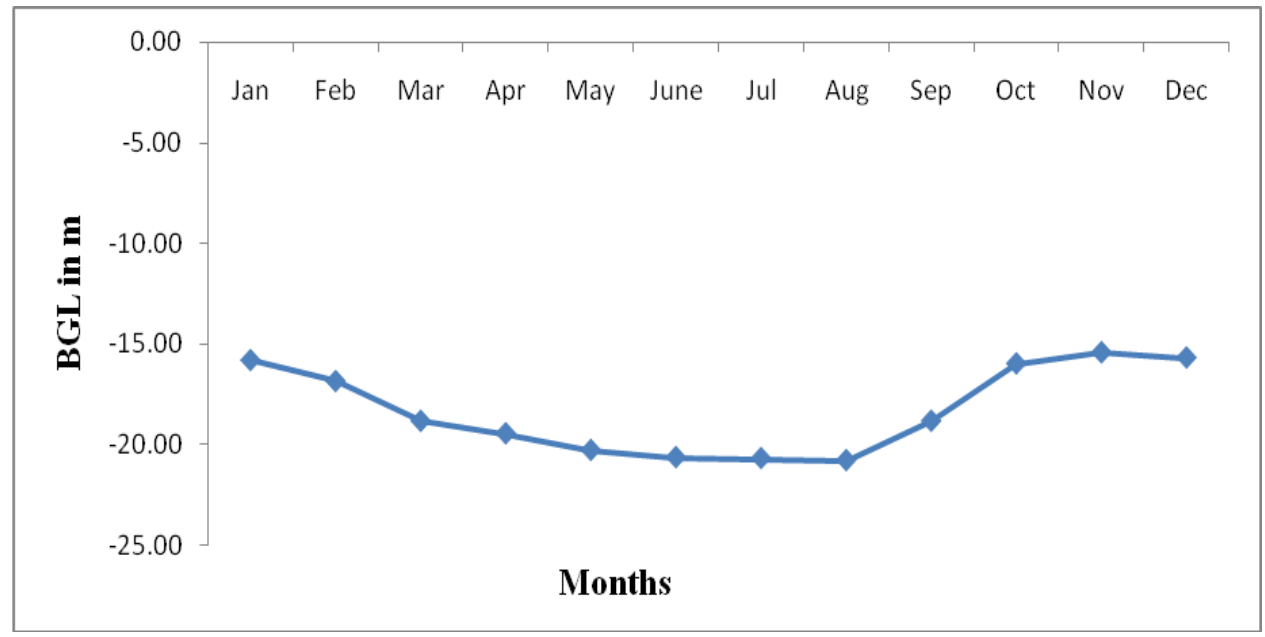


It was found that there is no recharge of ground water from January-June months except in few cases. Ground water recharge takes place monsoon months of June to December. However during 2008 the highest ground water recharge was noticed during September 2008 i.e. $12320 \mathrm{~mm}$ as shown Figure 2. From the average piezeometric values for last 12 years obtained from Vadrapalem village, Madakasira Mandal. It was found that the ground water fluctuations between i.e. $15.78 \mathrm{~m}$ below ground level in January to $20.77 \mathrm{~m}$ in the month of August. Hence this data is useful designing appropriate water lifting devices in this region as shown Figure 3. Similarly work related to the present investigation was also carried out by Bhagyashri et al., (2011); Enokela et al., (2012); Gosselin et al., (2006) and Patil and Saptarshi (2012).

Conclusions of the study are as follows:

The Vadrapalem village in the September, 2008, there was highest ground water recharge i.e. about $12.32 \mathrm{~m}$ or $12320 \mathrm{~mm}$. This is due to highest amount of rainfall received in September, 2008. Generally July to December are the months varying the ground water levels are increasing. Similarly during the months from January to June there is no recharge of ground water.

In Vadrapalem in the months January to June there was absolutely no recharge at all the 11 years. There was minimum recharge (fluctuations) from June to December months. From this analysis we can design the crop calendar based on ground water recharges and also it has been from the January to July are driest months in this region.

These study high lights the water dynamics in Ananthapuram district. Based on the study the researches, Administrators can plan advocating for various crop management practices and crop insurance, and the former oriented approaches.

\section{References}

Bhagyashri C., Maggirwar and Bhavana N. Umrikar (2011). Influence of various factors on the fluctuation of groundwater level in hard rock terrain and its importance in the assessment of groundwater. Journal of Geology and Mining Research. 3 (11): 305317.

Enokela O. S., Egarevba N. A and Isikwue M. O., (2012). Trend in ground water fluctuation in Gidan Kwano Inland Valley of Niger State Nigeria. Journal of Engineering and Technology Research. 4(7):129-135.

Gosselin D.C., Sridhar V., Harvey F.E. and Goeke J.W (2006).Hydrological effects and groundwater Fluctuations in interdunal environments in the Nebraska Sand hills. School of Natural Resources Institute of Agriculture and Natural Resources University of Nebraska-Lincoln 102 Nebraska Hall Lincoln.

Jiu J.J and Zhonghua Tang (1999). An analytical solution of groundwater response to tidal fluctuation in a leaky confined aquifer. Water resources research, vol. 35, no. 3, pages 747-751.

Pandurang Patil and Praveen G. Saptarshi (2012), groundwater fluctuation in the Pondhra Watershed Basin of KarmalaTahsil, Solapur. Universal Journal of Environmental Research and Technology.

\section{How to cite this article:}

Laxman, B., M.V. Ramana and Tirupathi, S. 2018. A Study on Groundwater Recharge and Fluctuation of Vadrapalem Village in Madakasira Mandal of Andhrapradesh, India. Int.J.Curr.Microbiol.App.Sci. 7(07): 1538-1541. doi: https://doi.org/10.20546/ijcmas.2018.707.181 